\title{
A arte do discernimento em Santa Teresa de Ávila
}

\author{
Orientador: Prof ${ }^{a}$ Lúcia Pedrosa de Pádua
}

Pesquisadora: Raísa Suena Soares Lopes

\section{Fonte: CNPq}

\section{Introdução}

A proposta da pesquisa foi investigar, a partir da autobiografia de Santa Teresa de Ávila, o Livro da Vida, a arte do discernimento. Procuramos demonstrar que a importância do discernimento reside não só no fato de que este nos auxilia na busca de sentido e equilíbrio, mas também, na possibilidade de compreender e corresponder, de alguma forma, aos mistérios da vida, a partir de compromisso com a verdade e, consequentemente, a partir de uma responsabilidade pessoal e comunitária. Dizemos, por fim, que o discernimento é a comunicação entre Deus e o homem e, neste, o impulso, o desejo por querer fazer a vontade daquele, que, gratuitamente, lhe deu a vida.

\section{Objetivos}

Não raro, no dia-a-dia, deparamo-nos com situações que exigem de nós escolhas. A ação de escolher, portanto, é muito própria do ser humano. E não é difícil constatar que, de modo geral, somos aquilo que escolhemos. Pudemos perceber também que tanto mais em crise está o ser humano tanto mais sente a necessidade de tomar decisões para retomar ao equilíbrio primevo.

Tendo, pois, feito esta análise, atentamos ao fato de que vivemos tempos de profunda perda de sentido (de vida). Desse modo, dizemos que o tema do discernimento é atual. Por isso, tivemos como objetivo principal, nesta pesquisa, desenvolver o presente tema e sua aplicação na vida do ser humano. E os seguintes objetivos específicos: conceituação do termo discernimento e apresentação de alguns de seus pressupostos; abordagem do tema a partir da pessoa de Teresa de Jesus e, mais especificamente, a partir do Livro da Vida, já 
que este nos oferece uma distinta contribuição para o caminho de muitos que desejam, assim como ela, "tratar intimamente com aquele que sabemos que nos ama" (Vida 8, 5) e fazer sua vontade. 